\title{
College impact, student impact: A reconsideration of the role of students within American higher education ${ }^{1}$
}

\author{
ERIC L. DEY \& SYLVIA HURTADO \\ Center for the Study of Higher and Postsecondary Education, University of Michigan, USA
}

\begin{abstract}
American college students tend to be viewed in terms of inputs and outcomes, due in part to the assessment movement and long-standing interest in college impact. A more complete view is one in which the relationship between students and the college environment is both reciprocal and dynamic. This ecological perspective portrays students as actively shaping their educational environments, with these environments simultaneously providing the potential for transforming the individual. Data from the Cooperative Institutional Research Program (CIRP) are used to explore the ecological perspective.
\end{abstract}

As the central constituency in American higher education, students have been given a tremendous amount of attention in the popular and scholarly literatures. Traditionally, undergraduates have been viewed by the ways in which their background attributes - such as character, preparation, gender, and race contribute to and help describe the culture and status of individual campuses and larger systems of higher education institutions. Clark, for example, notes that "students are important to the character of their institution" and that "the student body becomes a major force in defining the institution" (1970, p. 253). Selective admissions policies are often used to select students not only on the basis of academic criteria but on the basis of 'character' and the student's potential to contribute to the college in any number of ways (Klitgaard 1985). In addition, students and their perceived academic quality are often seen as an organizational resource and as a measure of institutional quality (Astin 1985).

More recently, it has become popular to think of undergraduates as the recipient of collegiate influences that produce certain psychological, social, and economic outcomes for individuals as well as the larger society. This perspective has been popularized by the assessment movement and scholarly interest in questions of college impact (Erwin 1991; Pascarella \& Terenzini 1991). From such a perspective, high quality programs and institutions are those which bring about the largest growth in student knowledge and personal development (Astin 1985; Jacobi, Astin \& Ayala 1987).

In addition to these main perspectives, it is also important to consider the ways in which students influence colleges and universities. This view, which acknowledges students as sources of institutional change, has received much less attention in the research literature (Altbach 1993). The most visible source of student-led change is protest and direct action, which is reinforced by the observation that an "inactive student body is a much more curious phenomenon than one which is involved to some degree in activism" (Lipset 1971, p. 263). Historically, student activists have tended to pursue agendas focused on broad social and political concerns (Altbach 
1993), although relatively recent examples of activism include student efforts to institutionalize ethnic studies and multicultural centers, prevent tuition increases, and urge institutions to develop proactive responses to racist and sexist situations on campus (Vellela 1988). It is important to note that not all student-led change comes about as a direct result of student protest or other forms of political action. In fact, a tremendous amount of such change develops as a result of natural institutional responses to changing student needs and preferences.

\section{An ecological perspective}

Although each of these views is useful in helping us understand different aspects of the role of students within higher education, they can also serve to artificially restrict the ways in which we view students. A more complete view is one in which the relationship between students and the college environment is seen as both reciprocal and dynamic. Such an orientation has been described as an ecological perspective (Alwin, Cohen \& Newcomb 1991; Bronfenbrenner 1979) and portrays students as actively shaping their interpersonal environments and, by extension, their institutions, with these environments simultaneously providing the potential for transforming the individual.

The ecological perspective is based on Bronfenbrenner's observations about the limitations inherent in the study of human development using traditional perspectives. Of particular concern to Bronfenbrenner was the lack of recognition paid in the research literature to the process of "progressive accommodation between a growing human organism and its immediate environment" (1979, p. 13). Although the importance of the interaction between individuals and environments in fostering human development has long been recognized, psychological research focused almost exclusively on aspects of the individual, to the neglect of the environment and its influence.

Research on students in higher education, in contrast, has long been concerned with environmental influences, yet the conception of the environment is similar to the traditional psychological perspectives described by Bronfenbrenner. In short, the environment is conceptualized as a "static structure that makes no allowance for the evolving processes of interaction" (Bronfenbrenner 1979, p. 17). Such a conception blinds us to the important processes of personal choice and organizational change that have been described as dynamic stability, or "the process by which the individual constructs circumstances which help maintain prior orientations and which in turn feed back on the person so as to maintain stability over time. The person is thus not only the recipient of influences from the environment; she is also an active agent in shaping that environment" (Mortimer $e t$ al., cited in Alwin, Cohen \& Newcomb 1991, p. 252).

In order to explore an ecological perspective of college students and the dynamic relationship between students and institutions, we will discuss two important social and educational trends that have helped shape American higher education over the past three decades: changes in the demography of higher education, and entering 
students' educational plans and preferences. We will also consider the changes in the experiences of students during college as a third group of data-based observations.

In examining these trends, we hope to show the utility of adopting an ecological perspective by highlighting patterns of institutional change that are related to these student trends. The interplay between students and institutions is both subtle and complex, where direct cause-and-effect relationships are difficult to detect. As such, we hope to illustrate this perspective by linking what we believe to be interrelated trends. Although our preference would be to provide a more definitive analysis, we are unaware of data resources which might allow this sort of analysis. As such is the case, our goal here is to encourage others to see the value of this perspective since it opens up new possibilities for studying students, institutions, and the processes that foster individual and institutional change.

The data on entering college students come primarily from the Cooperative Institutional Research Program (CIRP) coordinated by the Higher Education Research Institute at UCLA. The CIRP data are based on responses from an annual survey of some 250,000 students entering about 600 colleges and universities nationwide (see Astin, Korn \& Riggs 1993; Dey, Astin \& Korn 1991). Given the large sample sizes we are dealing with, any differences large enough to be interesting are going to be statistically significant. As such, we will refrain from showing formal statistical tests. It should also be recognized that the CIRP focuses primarily on what might be considered "traditional" American students, so the patterns discussed are likely to understate the extent to which changes have occurred in the general college population. Data on the changing pattern of incollege experiences of students is based on various sets of longitudinal surveys of college students who participated in the CIRP freshman surveys and who were followed-up several years later (see Astin \& Panos 1969; Green, Astin, Korn \& McNamara 1983; Higher Education Research Institute 1992).

\section{The changing demography of higher education}

Despite the many changes that have occurred in access to and enrollment in American higher education over the past several decades, we suspect that the traditional image of college students is surprisingly persistent. One reason that traditional images are common is that we tend to think of specific generations of college students when trying to describe their attributes. Unfortunately, truth and fiction are intertwined in the stereotypes that become attached to each generation.

At the same time, it is important to note that some of these generational stereotypes do come close to describing groups of students at particular institutions. To be sure, some institutions continue to seek and enroll students that fit a "traditional" college student inage, while others have taken on more diverse clienteles in order to better serve changing state and local populations. This, then, suggests that there have been changes not only in the type of student now attending college, but there are also related changes in institutional mission and policy that 
help differentiate institutions across the higher education system. The enrollment patterns associated with the changing demography of higher education have helped to transform the nature of our institutions.

Spurred on by the great social movements of the 1960s, American higher education enrollments have grown considerably and continue to expand (U.S. Department of Education 1992). Despite predictions of a declining number of college-age students, we witnessed a 16 percent increase over the last decade and a record enrollment of 14.4 million students in 1992. Much of the growth over the last three decades has been due to increased access for non-traditional students. Adults over the age of 25 have been the fastest growing group, and currently represent over 40 percent of all students in higher education. There has also been a shift toward part-time enrollment in higher education since 1965, with part-time students now representing about 43 percent of all students.

In addition to the changes wrought by the large numbers of "nontraditional" students, striking changes in the composition of college entrants have also redefined our conception of the "traditional" college student. Table 1 shows the changing demographics of first-time, full-time students entering four-year colleges. A typical American college student in the 1990s is likely to be female: women constituted 53 percent of first year students pursuing a baccalaureate degree in 1991 , compared to 44 percent in 1961. As a result of society's changing views of women's roles, coupled with institutional initiatives to enroll more women and an overall increase in the level of educational attainment, today's college student is also more likely to have a mother who has completed a college degree. The proportion of older students attending college for the first time has also steadily increased over time. These changes in the traditional college-going population indicate that child care services, re-entry services, women's centers, women's studies, and incorporating gender-related issues in the classroom will continue to be salient for increasing proportions of campus communities.

Improved access for students of diverse socioeconomic backgrounds is one of the most significant trends of the last three decades that warrants monitoring in the future. The median family income of traditional students attending college in the 1960s was almost twice as high as the national median income. This gap was dramatically reduced by the federal financial aid policies that enabled students of diverse economic backgrounds to pursue a college education. Although national family incomes steadily increased, the trend toward closing the gap between national family income and the families of four-year college students stagnated during the 1980s. This lack of progress toward economic equity may be largely attributable to changes in the federal student aid programs during the Reagan-Bush administrations, rapidly rising college tuition rates, as well as recent economic problems (College Board 1989). The combined effect of these factors during the 1980s suggests that four-year colleges will face the challenge of recruiting and retaining students of diverse economic backgrounds in the years to come.

Table 1 also shows that the proportion of white students has steadily declined, while the representation of all other ethnic minority groups has increased among first-time entrants to four-year colleges. Increased access over the years, coupled 
Table 1. Demographic Characteristics of New Students Entering Four-Year Colleges, 1961-1991

\begin{tabular}{lcccr}
\hline & 1961 & 1971 & 1981 & 1991 \\
\hline Percent women & 44 & 46 & 51 & 53 \\
$\begin{array}{l}\text { Percentage of students with mothers } \\
\text { who held a college degrec }\end{array}$ & 21 & 22 & 30 & 39 \\
Age distribution & & & & \\
$\quad 18$ or younger & - & 78 & 76 & 69 \\
19 or older & - & 23 & 25 & 31
\end{tabular}

Socioeconomic background

$\begin{array}{lrrrr}\text { Median freshman family income } & 45,922 & 41,770 & 40,289 & 43,600 \\ \text { National median family income } & 24,864 & 33,238 & 33,346 & 35,353 \\ \text { Ratio, national to freshman income } & .54 & .80 & .83 & .81\end{array}$

Raciallethnic background

White/Caucasian

African-American/Black

American Indian

Asian-American/Oriental

Mexican-American/Chicano

Puerto Rican

Other

$\begin{array}{rrrr}97 & 91 & 87 & 78 \\ 2 & 7 & 9 & 12 \\ Z & 1 & 1 & 2 \\ 1 & 1 & 1 & 4 \\ - & \mathrm{Z} & 1 & 2 \\ - & \mathrm{Z} & 1 & 1 \\ \mathrm{Z} & 1 & 2 & 2\end{array}$

Notes: Racial/ethnic labels vary between survey years. Racial ethnic percentages may total more than 100 after 1971 due to multiple responses of students. Family income estimates given in 1990 dollars. Due to differences in response options for mother's education, postsecondary certificate holders are included with high school graduates; those with some graduate school are included with college graduates. $Z$ indicates less than 0.5 percent; - indicates data not available.

Source: 1961 data are from Astin and Panos 1968; 1971 and 1981 data are from Dey, Astin, and Korn 1991; 1991 data are from Dey, Astin, Korn, and Riggs 1992. National median family income estimates are from the Statistical Abstract of the United States, 1992, Table 703, and Current Population Reports (Series P-60), No, 80.

with the growing representation of minorities within college-age cohorts, have changed the ethnic composition of many campuses. As a result, campuses will need to continue the restructuring process of becoming multicultural environments. What is not evident from this table, however, is that while all racial and ethnic groups have recorded enrollment gains, some ethnic groups continue to face considerable inequities in access to college. For example, although Hispanics posted gains, they have experienced an actual decline in their college participation rate (Carter \& Wilson 1992). Both Native Americans (52 percent) and Hispanics (55 percent) are also more likely to be represented in two-year colleges than either African American or white students (42 and 37 percent respectively) (U.S. Department of Education 1992).

These changing characteristics of America's college students are a direct result of a combination of demographic growth, changing social views, government 
policies, and institutional initiatives to recruit students from all potential college populations. Some institutions, for example, have altered their missions and strengthened their commitment to serving special populations. Such changes would have been impossible without the equity reform movements that brought about changes in the nation's collective consciousness as well as tangible federal assistance in the form of financial aid policies. We have witnessed the development of tribal colleges, a strengthened position of many historically black and women's colleges, and now an increasing number of Hispanic-serving institutions. ${ }^{2}$ In each of these specific cases, student characteristics have helped give further definition to the institution's mission. Aside from these special types of institutions, we are also witnessing a gradual transformation of "traditional" institutions as they respond to the new student populations by creating new services (Pearson, Shavlik \& Touchton 1989; Smith 1989) and incorporating new perspectives in the curriculum and extracurricular programming (Andersen 1988).

While these changes may appear to have occurred rapidly, change continues to come about slowly for those who confront institutional resistance. A college's historical legacy of exclusion of specific groups may, for example, continue to influence seemingly "neutral" institutional policies (Hurtado 1994). Generating a commitment to institutional transformation among administrators and faculty who refuse to examine their own attitudes and practices that affect students remains one of the greatest challenges (Aiken, Anderson, Dinnerstein, Lensink \& MacCorquodale 1988). Thus, ideologies at the institutional and individual level continue to present barriers to recognizing and meeting the needs of the new American college student.

\section{Educational plans and preferences}

In addition to the changing composition of students, there have been changes in student plans and preferences for college. Some of these patterns appear to be clearly related to student experiences in high school, some are related to larger economic forces, and others seem more closely related to social forces like changing views about the role of women in American society. First, we consider the issue of student academic experiences during high school and how this appears to relate to their expectations for the college experience.

The data in Table 2 show an interesting and complex pattern of changes with regard to student preparation. The top panel of data show that students are now entering college with higher grade point averages than in the past. The percentage of students earning A grades in high school essentially doubled between 1966 and 1993 (from 15 to 27 percent, respectively), while the percentage earning $C$ or worse grades fell by one-half ( 31 to 16 percent). The relatively high level of student academic success before college appears to have influenced the expectations that students have for college: the CIRP data show strong increases between 1973 and 1993 in the percentage of entering students who expect to earn at least a B average in college, graduate with honors, and be elected to an academic honor society. Over 
Table 2. High School Experience Trends And Expectations for College, Various Years

\begin{tabular}{|c|c|c|c|c|}
\hline High school grade point average & 1966 & 1975 & 1984 & 1993 \\
\hline $\mathrm{A}$ or $\mathrm{A}+$ & 15 & 18 & 20 & 27 \\
\hline $\mathrm{B}-$ to $\mathrm{B}+$ & 54 & 60 & 58 & 57 \\
\hline $\mathrm{C}+$ or less & 31 & 21 & 22 & 16 \\
\hline \multicolumn{2}{|l|}{ Estimated chances are very good that they will } & 1973 & 1983 & 1993 \\
\hline Make at least a $B$ average & & 35 & 41 & 47 \\
\hline Graduate with honors & & 9 & 12 & 16 \\
\hline Be elected to an academic honor society & & 5 & 7 & 9 \\
\hline Fail one or more courses & & 2 & 1 & 1 \\
\hline Get tutoring help in specific courses & & $7^{1}$ & 9 & $16^{2}$ \\
\hline \multicolumn{5}{|l|}{ Student expects to need special tutoring or remedial } \\
\hline work during college in & & 1982 & 1994 & 1993 \\
\hline English & & 11 & 11 & 12 \\
\hline Reading & & 4 & 5 & 5 \\
\hline Mathematics & & 22 & 27 & 29 \\
\hline Social studies & & 2 & 3 & 4 \\
\hline Science & & 9 & 10 & 11 \\
\hline Foreign language & & 7 & 10 & 11 \\
\hline \multicolumn{4}{|l|}{ Met or exceeded recommended levels of high school } & 1992 \\
\hline English ( 4 years) & & 93 & 95 & 96 \\
\hline Mathematics ( 3 years) & & 85 & 92 & 93 \\
\hline Foreign language ( 2 years) & & 66 & 79 & 79 \\
\hline Physical science ( 2 years) & & 52 & 50 & 47 \\
\hline Biological science (2 years) & & 34 & 35 & 35 \\
\hline
\end{tabular}

Note: Curricular recommendations based on A nation at Risk (National Commission on Excellence on Education, 1982).

${ }^{1}$ Question not asked in 1973; data from 1975 reported.

${ }^{2}$ Question not asked in 1993; data from 1992 reported.

Source: Dey, Astin, \& Korn 1991; Astin, Korn, \& Riggs 1993.

the same period, the percentage of students expecting to fail one or more courses dropped by one-half. In combination, these patterns might suggest that students today are better prepared than those entering college two decades ago.

At the same time, these data also reveal a very different perspective. Despite the high levels of academic success prior to college, students also report that they are in need of additional academic support services. For example, the percentage of students who believe that there is a 'very good chance' that they will get tutoring help in specific courses during college more than doubled between 1975 and 1992, from 7 to 16 percent. Similarly, the percentage of students who expected to get special tutoring or remediation in mathematics, science, and foreign language increased between 1984 and 1993. What makes this interesting is that over the 
same period, students were more likely to meet recommended levels of preparation in many of these fields. For example, more than 93 percent of students who entered college in 1993 had at least three years of math during high school (up from 85 percent in 1984), while three out of every ten students expected to need special tutoring or remediation in math (up from 22 percent in 1982).

Taken together, these trends suggest that there has been something of a redefinition of the relationship between academic coursework on the high school level and skills related to those courses. This puts tremendous pressure on college and university faculty to work with students who have been very academically successful in high school and met or exceeded recommended levels of high school study, but who may nevertheless be underprepared for college-level work as traditionally defined.

Next we consider the changing patterns of preferences that students express for various undergraduate majors when they enter college (Table 3). This is an important consideration since beyond all of the educational philosophy that goes into designing a curriculum, a college's ability to maintain its curricular focus is necessarily dependent upon its ability to enroll students in the courses it offers. From a traditional liberal-arts perspective, the past 25 years have not been good ones with regard to interest in liberal arts fields among entering students: interest in majoring in the humanities, the fine and performing arts, and the social sciences has been declining consistently. Interest in majoring in English, for example, dropped by nearly three-quarters between 1967 and 1992. Interest in majoring in biological or physical sciences has remained somewhat stable since the 1960 s, while interest in mathematics and statistics has experienced a large decline, dropping from 4

Table 3. Undergraduate Major Preferences Among Entering College Students

\begin{tabular}{lrrrrrr}
\hline & \multicolumn{5}{c}{$\begin{array}{c}\text { Percentage of Entering College Students } \\
\text { Expressing }\end{array}$} \\
\cline { 2 - 7 } & \multicolumn{7}{c}{$\begin{array}{c}\text { En Interest in Various Majors in } \\
\end{array}$} & 1967 & 1972 & 1977 & 1982 & 1987 & 1992 \\
\hline Biological sciences & 4 & 4 & 5 & 4 & 4 & 5 \\
Business & 16 & 16 & 22 & 24 & 27 & 16 \\
Education & 11 & 7 & 9 & 6 & 9 & 10 \\
Engineering & 10 & 7 & 9 & 13 & 9 & 9 \\
English & 4 & 2 & 1 & .8 & 1 & 1 \\
Health professions (nursing, pre-med, etc.) & 5 & 11 & 10 & 9 & 7 & 16 \\
History and political science & 7 & 4 & 3 & 2 & 3 & 3 \\
Humanities & 5 & 4 & 2 & 2 & 3 & 2 \\
Fine arts (applied and performing) & 9 & 9 & 6 & 4 & 5 & 5 \\
Mathematics or statistics & 4 & 2 & .8 & .6 & .6 & .6 \\
Physical sciences & 3 & 2 & 2 & 2 & 2 & 2 \\
Social sciences & - & 8 & 5 & 4 & 6 & 6 \\
Undecided & 2 & 5 & 5 & 5 & 7 & 7 \\
\hline
\end{tabular}

Note: - indicates comparable data not available.

Source: Cooperative Institutional Research Program Trends File, Higher Education Research Institute, UCLA. 
percent in 1967 to 0.6 percent in 1992 . Although the relatively new and developing field of computer science may have captured some of the students who otherwise might have majored in mathematics or statistics, the 85 percent decline in the number of students who enter college with an interest in math and statistics is quite alarming. Interest in the engineering fields has been relatively stable over the past several years after peaking in the early 1980 s.

Table 3 also shows that the greatest changes in the popularity of different fields is associated with the field of business. After a period of relative stability, the percentage of students interested in business majors increased sharply during the late 1970s and 1980s. During the past few years, however, interest in business has stopped its climb and is currently in steep decline, with student interest now equal to that registered in 1967. The cause for this turnaround is not clear: it may be that competition for jobs has increased in the recent economic slowdown, or that many students are simply disillusioned with the field of business because of scandals such as insider trading, stock fraud, and the savings and loan debacle of the $1980 \mathrm{~s}$. While the explanation for these trends may not be clear, one thing is: institutions which rapidly expanded their business programs to take advantage of this growth in student interest may soon have to contend with the new problem of having too many highly-paid faculty in the field of business relative to student demand. This problem may be especially troublesome for the many small liberal arts colleges which avoided closure during the 1980 s by moving away from a traditional liberal arts program to incorporate business education into the curriculum (see Breneman 1993).

While interest in business is now in steep decline after record-setting increases, interest in majoring in the health professions has been increasing rapidly and is now at an all-time high. This surge of interest may well reflect the students of today who seem to be searching for majors that will lead to profitable and stable careers since business has apparently lost its attraction. It will be more difficult for colleges and universities to respond to this increased interest since education for the health professions, which is largely based in the sciences, is inherently more expensive than that associated with the field of business. Moreover, it is impossible to predict how long this trend will last.

Given the pronounced changes in the major field choices of students entering college, it is not surprising to find that the educational preferences of women have also changed quite dramatically. Table 4, for example, shows trends in aspirations for various postgraduate degrees and interest in different undergraduate majors over the past two decades. This table shows the number of women students interested in certain degrees and fields of study for every 100 men interested in the same option. If men and women were equally likely to aspire to a certain degree we would, for example, see 100 women per 100 men expressing an interest.

These changes clearly show the effectiveness of the women's movement in changing the way that women (and to a lesser extent men) think about certain degrees and careers. For example, with respect to postgraduate degree aspirations upon entry into college, Table 4 shows that women have essentially reached a point of parity. Indeed, aspiration for law and medical degrees among women now 
Table 4. Academic Plans of New College Students by Gender

\begin{tabular}{|c|c|c|c|}
\hline & \multicolumn{3}{|c|}{$\begin{array}{l}\text { Number of Women per } 100 \text { Men } \\
\text { Aspiring to Selected Degrees } \\
\text { and Undergraduate Majors in }\end{array}$} \\
\hline & 1972 & 1982 & 1992 \\
\hline \multicolumn{4}{|l|}{ Postgraduate degree aspiration } \\
\hline Law & 32 & 81 & 106 \\
\hline Medical & 44 & 90 & 103 \\
\hline Doctoral & 64 & 86 & 99 \\
\hline \multicolumn{4}{|l|}{ Undergraduate major field preferences } \\
\hline Biological sciences & 64 & 103 & 102 \\
\hline Business & 80 & 115 & 91 \\
\hline Education & 329 & 375 & 286 \\
\hline Engineering & 3 & 16 & 16 \\
\hline English & 278 & 167 & 167 \\
\hline Health professions (nursing, pre-med, etc.) & 550 & 331 & 239 \\
\hline History or political science & 54 & 69 & 83 \\
\hline Humanities & 204 & 163 & 121 \\
\hline Fine arts (applied and performing) & 124 & 102 & 60 \\
\hline Mathematics or statistics & 100 & 117 & 71 \\
\hline Physical sciences & 27 & 38 & 54 \\
\hline Social sciences & 227 & 275 & 247 \\
\hline
\end{tabular}

Source: Cooperative Institutional Research Program, Higher Education Research Institute, UCLA.

slightly exceeds that of men. It is important to note, however, that this pattern changes after four years in college: The number of women per 100 men aspiring to law, medical, and doctoral degrees is 91, 51, and 92, respectively (Higher Education Research Institute 1992). The marked drop in aspirations for medical degrees for women relative to that of men underscores the possibility that the undergraduate environment is relatively unsupportive for women aspiring to become physicians.

The bottom panel of Table 4 show how women's preferences for different fields of study have been changing, and reveal a mixture of trends. For example, in the fields where women were most underrepresented in 1972 - Engineering, history and political science, biological sciences, and physical sciences - we see a pattern of progress toward parity that varies by field. Engineering, for example, had the smallest representation of women in 1972, and this fact remains true two decades later. Despite a five-fold jump in interest in this field between 1972 and 1982, there has been no real change since that time. There may still be strong institutional barriers - such as heavy mathematical course requirements without a realistic possibility of remediation, and a male-dominated climate that is unwelcoming for women - that are preventing interest levels from moving beyond this plateau. The other science fields with an early underrepresentation of women have fared differently: women's interest in the biological sciences moved quickly to a position 
of parity, while the physical sciences still have a long way to go despite the doubling of interest that occurred. History and political science have also made progress in attracting the interest of women, but still remain far below a point of parity.

Other fields have also shown gender differences in patterns of student interest. Education, for example, shows a declining rate of interest among women despite the fact that it remains strongly dominated by women. The health professions which in addition to medicine includes the large, female-dominated field of nursing - now attracts the interest of fewer women relative to men than in the past. In the fields of English, the humanities, and the fine arts we have also seen a lessening of interest among women, with the decline in interest so sharp in the fine arts that women are now underrepresented. Women are now also underrepresented in the field of business, after reaching and exceeding a position of parity in the 1980s.

All of these changes will continue to have an impact on institutions as they attempt to balance their traditional educational missions with the changing interests of students. This is especially true of the changing patterns of interest among women and members of other underrepresented groups as such trends bring with them pressure to remove inequities and achievement barriers for these groups. In addition to influencing institutional policy and practice, these shifts in student interest are also linked to larger social and economic forces (such as the projected job market), and have direct implications for the nation's talent pool. The continued advancement of all fields of practice or inquiry is determined in good part by the pool of student talent in each particular field, and higher education's ability to help meet social and economic needs.

\section{Experiences during college}

As one might expect, given the many changes we have described, there have been changes in the nature of the college student experience. Table 5 shows changes in student academic performance, activities, and student satisfaction during college from the late 1960s to the beginning of this decade. Perhaps one of the most striking changes has been the shift toward earning high grades in college and a related drop in the proportion of students who earn less than a ' $B-$ ' since the late 1960s. This indicates that performance and academic success in college has been redefined, creating a certain amount of grade inflation relative to earlier eras. This may reflect the fact that students have become more grade conscious over the years and may be more likely to contest their grades. However, it may that this trend is fueled by external pressure because maintaining good college grades has become more closely linked to such economic considerations as the receipt of financial aid, auto insurance discounts, and access to graduate schools and jobs after college. At the same time that there are more students making high grades, it appears to be more difficult for students to graduate with honors.

Despite the changing political views of students and the persistent (and somewhat contradictory) images of the typical college student as an activist or a 
Table 5. Trends in Student Experiences During College, 1966-70 and 1987-91

\begin{tabular}{|c|c|c|c|}
\hline & $1966-70$ & $1987-91$ & $\begin{array}{l}\text { Percentage } \\
\text { difference }\end{array}$ \\
\hline \multicolumn{4}{|l|}{ Undergraduate grade point average } \\
\hline $\mathrm{A}$ or $\mathrm{A}+$ & 1 & 6 & 5 \\
\hline $\mathrm{A}-$ or $\mathrm{B}+$ & 5 & 27 & 22 \\
\hline $\mathrm{B}$ & 21 & 36 & 15 \\
\hline $\mathrm{B}-$ or $\mathrm{C}+$ & 35 & 24 & -11 \\
\hline $\mathrm{C}$ & 26 & 7 & -19 \\
\hline $\mathrm{C}$ - or less & 13 & 2 & -11 \\
\hline \multicolumn{4}{|l|}{ Activities since entering college } \\
\hline Joined a fraternity or sorority & 20 & 21 & 1 \\
\hline Graduated with honors & 14 & 12 & -2 \\
\hline \multicolumn{4}{|c|}{ Frequent activities during student's last year of college } \\
\hline Drank wine or liquor & 12 & 22 & 10 \\
\hline Drank beer & 30 & 38 & 8 \\
\hline Stayed up all night & 8 & 14 & 6 \\
\hline \multicolumn{4}{|c|}{ Participated in an organized demonstration/ } \\
\hline protest $^{*}$ & 19 & 18 & -1 \\
\hline Attended a religious service & 33 & 25 & -8 \\
\hline Smoked cigarettes & 27 & 12 & -15 \\
\hline \multicolumn{4}{|c|}{ Percent of students who were satisfied with: } \\
\hline Overall quality of instruction & 92 & 90 & -2 \\
\hline \multicolumn{4}{|c|}{ Opportunity to discuss coursework with } \\
\hline professors outside of class & 84 & 88 & 4 \\
\hline Lab facilities & 90 & 88 & -2 \\
\hline Library & 83 & 83 & 0 \\
\hline Overall satisfaction & 74 & 87 & 13 \\
\hline
\end{tabular}

*Percentage includes those students marking 'frequently' or 'occasionally'.

Source: Unpublished tabulations, Higher Education Research Institute, UCLA.

member of a fraternity/sorority, we find very little change in the proportion of students who actually participated in either of these activities since the 1960s. This suggests that these two activities are relatively 'generation free' in the sense that a roughly stable proportion of students participate. Despite the apparent constancy in the proportion of students involved in these activities, different generations of students become closely associated with these images due to larger social and political contexts. For example, even though a minority of students participated in demonstrations in the late 1960s, the general perception of this era is somewhat different.

In terms of alth and social behavior, students today are less likely to report frequent smoking due in part to increased health awareness and related restrictions on smoking in schoul, work, and places of entertainment. However, a higher 
proportion of students reported that they drank wine, liquor or beer in college than in the late 1960s. While most of the students surveyed here would meet drinkingage requirements by their fourth year of college, it is difficult to restrict their associations with other students who are under the age limit. This shift in student behavior makes it extremely problematic for colleges to monitor and comply with legislation that raised the drinking-age in the last decade. Colleges continue to provide opportunities for alcohol-free activities, but providing alternatives for healthy social lives will remain one of the continuing challenges for student affairs staff on campus.

Student satisfaction and retention are aspects of a student's experience that are closely related to college impact and institutional accountability. These data show that student satisfaction with the college experience has remained generally high over time, with only small changes in specific areas of satisfaction. Although students are somewhat less satisfied with lab facilities and the quality of instruction on campus, in the early 1990 s they were more satisfied with opportunities to discuss course work with professors outside of class. Overall satisfaction with college has increased from 74 percent in the late 1960 s to approximately 87 percent of college students at the beginning of this decade.

It is interesting to note that overall satisfaction remains high, even though student retention has changed over the years. Table 6 shows the proportion of three undergraduate student cohorts who were retained at the college they originally entered using two different retention rates. These data clearly show a decreasing proportion of each cohort that have obtained a degree in four years, while the proportion persisting through four years has remained relatively stable. Taken together, this suggests that students are simply taking longer to graduate than earlier cohorts. There is perhaps no single explanation for why students are taking longer to graduate. Students are now faced with additional financial pressures financial aid has shifted from grants to loans, and to avoid excessive debt, more students are working and attending college part-time (College Board 1989; Astin, Dey, Korn \& Riggs 1991). In addition, the anecdotal evidence suggests that some students are finding it difficult to enroll in required courses at many large institutions, while others may be delaying their completion by taking advantage of study abroad programs or other opportunities that broaden their experiences but lengthen the amount of time it takes to earn a degree.

Table 6. Trends in Undergraduate Retention Rates

\begin{tabular}{ccc}
\hline $\begin{array}{c}\text { Undergraduate } \\
\text { cohort }\end{array}$ & $\begin{array}{c}\text { Obtained a } \\
\text { Bachelor's degree }\end{array}$ & $\begin{array}{c}\text { Obtained a Bachelor's } \\
\text { degree or completed four years }\end{array}$ \\
\hline $1966-1970$ & 47 & 59 \\
$1978-1982$ & 43 & 56 \\
$1987-1991$ & 40 & 56 \\
\hline
\end{tabular}

Source: 1966-70 data are from Astin, 1971; 1978-82 data are from Green, Astin, Korn, and McNamara 1983; 1987-91 data are based on unpublished tabulations, Higher Education Research Institute, UCLA. 
Student retention will remain an important area of institutional accountability and we can expect that more institutions will begin to follow closely the progress of students and make efforts to improve their college experiences. It is clear that trends in student graduation rates have redefined persistence in such a way that we must monitor persistence from year to year and examine degree attainment rates over a longer time span. Six years has become the new guideline established by NCAA Division I institutions that many agree is more accurate that the four-year retention rate. Even so, only 53 percent of 1984 first-time, full-time students graduated in six years from their college (U.S. Department of Education 1992). Administrators, legislators, and the general public are becoming increasingly concerned about institutional retention rates while new federal regulations require that institutions report these rates.

\section{The complexity of the student role}

Changes in the composition of the undergraduate student body in American higher education force us to reconceptualize our notions of the typical college student, as well as their influence on institutions and society at large. Our examination of the trends across generations of college students encourages us to adopt a more complex view of the role of students in American higher education. When we think of students and change, we naturally think of the ways institutions influence students: students are supposed to be influenced by the educational programs in which they participate. However, the reverse is also true: many institutions undergo significant change in their recruitment strategies, services, and curricula as the constituencies they serve change.

The value of adopting an ecological perspective is underscored by the changing demography of higher education, trends in student political preferences and academic interests, and significant changes in aspects of the college experience we have reviewed. Service to special populations has become a central mission of some colleges, while changes in the type of students attending traditional four-year institutions reflect new needs and create new demands for institutional change. In contrast to student protests and political action, a tremendous amount of student-led change arises as the result of natural institutional efforts to serve student needs. Although many of these changes represent responses to recognized problems and come about with pressures from external constituencies (e.g., parents, alumni, taxpayers, legislators, peer institutions), they represent an attempt on the part of institutions to improve aspects of the educational process for students. Concern about student retention offers a prime example. Institutional efforts to improve retention rates have led to the creation of remedial programs in response to shifts in student preparation, the establishment of co-curricular programming to make the social environment more conducive for all students, and the improvement of academic counseling and opportunities for student-faculty contact.

Active attempts by students to change institutions through protest, and other 
forms of direct action, tend to receive the most attention. As noted above, relatively recent examples of activism include student efforts to institutionalize ethnic studies and multicultural centers, prevent tuition increases, and urge institutions to develop proactive responses to racist/sexist situations on campus (Vellela 1988). Such issues are especially important to the increased numbers of minorities, women, and students of diverse economic backgrounds on college campuses. In many cases, student protest has served as the impetus for institutional self-examination and the adoption of new institutional policy. Given the increasing amount of disaffection with traditional political methods among college students, and the numbers of entering students who report participating in demonstrations, we can expect to see continued protest activity when institutions are slow to respond to student needs or refuse to assume a leadership role in addressing matters of social concern.

Students can also actively resist attempts to be changed by institutions, and administrators may find it particularly problematic to change student social habits at institutions with strong student cultures. The trends in college student experiences show that drinking has increased even though new national policies designed to decrease alcohol use have been implemented. Institutional efforts designed to eliminate hazing, and racist or sexist games in fraternities have also been met with varied success. While the roots of this resistance may be based both in politics and popular youth culture, it is clear that institutional rules and regulations cannot guarantee success in changing student behavior regardless of the amount of input students have in developing such rules and regulations.

Finally, there are many areas that constitute problems for institutions simply because students have their own ideas and preferences. Perhaps the most troubling information we presented has to do with the future talent pool of students in specific fields. How can institutions influence students to pursue careers that will be vital in the future? At some level, students are attuned to job market opportunities, but their goals may not be synchronized with a changing economic future: By the time that students graduate from college with specific training, the availability of jobs in certain fields may have disappeared. The increasing rapidity with which economies have been changing suggests that the extended length of an undergraduate education will plague students seeking careers in fields where there is an unstable pattern of job growth.

Although we have a tendency to think of students in one of several unidimensional ways, a more complete view is one in which the relationship between student and the college environment is seen as both reciprocal and dynamic. Adopting this ecological perspective requires that we rethink the nature of the students' role in relation to institutions and the wider society. Students have proactively and subtly induced institutional and social change throughout history and will continue to do so in the future. These changes, in turn, have altered the nature of the student experience and the impact college has on students. We hope that those interested in higher education will begin to recognize and acknowledge these interconnections, and begin to view the role of college students in different and more complex ways. 


\section{Notes}

${ }^{1}$ Portions of this paper appear as a chapter in Altbach, P.G., Berdahl, R.O. and Gumport, P.J. (eds), Higher education in American society (3rd edition). Amherst, NY: Prometheus.

${ }^{2}$ Over the past two decades, 26 tribal colleges have been established and have steadily increased their enrollments (See O'Brien 1992). Women's colleges and historically black institutions have strengthened their position in terms of attaining a relatively stable and increasing student enrollment in the last ten years (Carter \& Wilson 1992; see also Touchton \& Davis 1991). Hispanic-serving institutions are defined by the Hispanic Association of Colleges and Universities (HACU) as institutions that meet a Hispanic enrollment minimum of 25 percent. An increasing number of institutions are expected to become Hispanic-serving towards the end of this decade (Hispanic Association of Colleges and Universities Annual Report, 1990).

\section{References}

Aiken, S.H., Anderson, K., Dinnerstein, M., Lensink, J. and MacCorquodale, P. 'Trying transformations: Curriculum integration and the problem of resistance', in Minnich, E., O'Barr, J and Rosenfeld, R. (eds), Reconstructing the academy: Women's education and women's studies. Chicago: University of Chicago.

Altbach, P.G. (1993). 'Students: Interests, culture, and activism', in Levine, A. (ed.), Higher learning in America 1980-2000. Baltimore, MD: Johns Hopkins University Press.

Alwin, D.F., Cohen, R.L. and Newcomb, T.M. (1991). Political attitudes over the life span: The Bennington women after fifty years. Madison, WI: University of Wisconsin Press.

Andersen, M.L. (1988). 'Changing the curriculum in higher education', in Minnich, E., O'Barr, J. and Rosenfeld, R. (eds), Reconstructing the academy: Women's education and women's studies. Chicago: University of Chicago.

Astin, A.W. (1985). Achieving educational excellence. San Francisco: Jossey-Bass.

Astin, A.W. (1993). What matters in college: Four critical years revisted. San Francisco: Jossey-Bass.

Astin, A.W., and Panos, R.J. (1968). The educational and vocational development of college students. Washington, DC: American Council on Education.

Astin, A.W., Dey, E.L., Korn, W.S. and Riggs, E.R. (1991). The American freshman: National norms for Fall 1991. Los Angeles: Higher Education Research Institute, UCLA.

Astin, A.W., Korn, W.S. and Riggs, E.R. (1993). The American freshman: National norms for Fall 1993. Los Angeles: Higher Education Research Institute, UCLA.

Breneman, D.W. (1993). 'Liberal arts colleges: What price survival?', in Levine, A. (ed.), Higher learning in America, 1980-2000. Baltimore, MD: Johns Hopkins University Press.

Bronfenbrenner, U. (1979). The ecology of human development: Experiments by nature and design. Cambridge, MA: Harvard University Press.

Carter, D. and Wilson, R. (1992). Minorities in higher education: Tenth annual status report. Washington, DC: American Council on Education, Office of Minority Concerns.

Clark, B.R. (1970). The distinctive college. Chicago: Aldine.

College Board. (1989). Trends in student aid: 1980 to 1989. New York: Author.

Dey, E.L., Astin, A.W. and Korn, W.S. (1991). The American freshman: Twenty-five year trends. Los Angeles: Higher Education Research Institute, UCLA.

Dey, E.L., Astin, A.W., Korn, W.S. and Riggs, E.R. (1992). The American freshman: National norms for Fall 1992. Los Angeles: Higher Education Research Institute, UCLA.

Erwin, T.D. (1991). Assessing student learning and development: A guide to the principles, goals, and methods of determining college outcomes. San Francisco: Jossey-Bass.

Green, K.C., Astin, A.W., Korn, W.S. and McNamara, P. (1983). The American college student, 1982 : National norms for 1978 and 1980 college freshmen. Los Angeles: Higher Education Research Institute, UCLA. 
Higher Education Research Institute. (1992). The American college student, 1991: National norms for 1987 and 1989 college freshmen. Los Angeles: Higher Education Research Institute, UCLA.

Hispanic Association of Colleges and Universities. (1990). Annual report. San Antonio, TX: Author.

Hurtado, S. (1994). The institutional climate for talented Latino students. Research in Higher Education, $35(4)$.

Jacobi, M.A., Astin, A.W. and Ayala, Jr., F. (1987). College student outcomes assessment: A talent development perspective [ASHE-ERIC Higher Education Report no. 7]. Washington, DC: George Washington University.

Klitgaard, R. (1985). Choosing elites. New York: Harper \& Row.

Lipset, S.M. (1971). Rebellion in the university. New York: Little, Brown \& Company.

O'Brien, E.M. (1992). American indians in higher education [ACE Research Brief]. Washington, DC: American Council on Education.

Pascarella, E.T. and Terenzini, P.T. (1991). How college affects students. San Francisco: Jossey-Bass.

Pearson, C., Shavlik, D.L. and Touchton, J.G. (1989). Educating the majority: Women challenge tradition in higher education. New York: ACE/Macmillan.

Smith, D. (1989). The challenge of diversity: Involvement or alienation in the academy [ASHE-ERIC Higher Education Report no. 5]. Washington, DC: George Washington University.

Touchton, J.G. and Davis, L. (1991). Factbook on women in higher education. New York: ACE/Macmillan.

U.S. Department of Education. (1992). Unpublished tabulations cited in The Chronicle of Higher Education Almanac (1993, August 25). Washington, DC: Chronicle of Higher Education.

Vellela, T. (1988). New voices: Student activism in the'80s and '90s. Boston: South End Press. 